\title{
Hormonal Effects on the Biosynthesis of Tobacco RuBPCase in vitro*
}

by

\author{
S. D. Kwrig and P. R. Rbodes \\ Department of Biological Sciences, University of Maryland Baltimore County, \\ Catonseille, Maryland, U.S.A.
}

and

G. W. Smeeffer and T, C. Tso

Cell Cadture and Nitrogen Fixation and Tobaeco Laboratories, US. Department of Agrickltures

Beltsvilie, Matyliand, U.S.A.

\section{INTRODUCTION}

Historically, ribulose 1,5-bisphosphate carboxylase/oxygenase (RuBPCase) was discovered from studies of proteins from green lenves and named Fraction I protein (FI protein) (1). This protein was once assurned to be associated with bormone acrion. More than 30 years have passed since then and out knowledge of this protein bas advanced considerably (2); yet, very little information is available on the bormonal effect upon this protein. Some stimulating effects on the synthesis of RuBPCase have been reported recently for eytobinin-treated rye seedlings (3). This effect is probabiy associated with a cyrokivin stimulation of the syathesis of the large subunit (3), which is known to be coded by diloroplast genes and syathesized on chloroplest ribosomes (4). This prompted us to investigate the effects of auxin and cytokinin on the regulation of the biosynthesis of RuBPCase and on dloroplass ribosomes in vitro.

The tobacco plant tested bere was the mutant of John Williams Broadleaf (J.W,B.). 'This mutent in the heterozygous (Su/su) form is yellow and provides two homozygous segresants (Su/Su and su/su) and the parental type (Su/su) from self-pollination in the Mendelian fashion (5). The bomozygous dominant ( $\mathrm{Su} / \mathrm{Su}$ ) is albino, lethal 25 seedling and does not grow autotrophically under greenhouse conditions. Both the bomozygous, recessive (st/su), which is the wild type, and the hererozygous (Su/su) yellow form grow well in the greenhouse and produce normal seeds. When cultured in vitro on an

- Recrivedt 28th Aprll 1980- reciprod: 4th Noperbar 1980. agar medium supplemeared with sucrose and hormones, all tbree genorypes used in this study grow equally well $(6,7)$.

In this paper, we wish to report our findings on the regulation of the biobynthesis of RuBPCase by the plant hormones indole-3-acetic acid (LAA) and kinetin. The implication of such regulation is discussed.

\section{MATERIALS AND METHODS}

Seedlings: Seed from solf-pollinated, yellow mutant plants (Su/su) were surface sterilized with $20 \%$ bousehold Clorox for 15 min and placed on $1 \%(w / v)$ agar containing a modifjed Murashige-\$koog (MS) medium (B), with or Fithout indole-3-acetic acid (IAA), kinetin or borh. The medium was adjusted to $\mathrm{pH} 5.5$ and autoclaved for 15 trin at 15 psu. About 15 seeds were placed in each 125 ml Erlenmeyer flask containing $30 \mathrm{ml}$ solid agar medium. The seeds were germinated with or without sucrose. Fourteen days after germination, excess seedlings were removed with forceps, leaving only the desired phenotype, ubually three seedlings a flask.

Plantlets: Soveral $5 \mathrm{~mm}$ stem sections immediately below the cotyledons of cwo-week old seedlings, described above, were excised and cultured on a full strengch MS medius supplemented with glutanine (10-' M), myoinositol (5.5 $\times 10^{-6} \mathrm{M}$ ), glycine $(2 \mathrm{mg} / \mathrm{l})$, vitemins $(2 \mathrm{mg} / \mathrm{l})$ and iron $\left(\mathrm{FeSO} \cdot \mathrm{H}_{2} \mathrm{O}\left(10^{-4} \mathrm{M}\right)\right.$ ), as previously described (7). Suerose was ubed as the carbon source for the development of plantlets. 
The plant hormones, IAA and kinetin, were added either alone or in combination at the concentration of $1 \mathrm{mg}$ per liter (7). Plant materials were maintained under continuous cold white fluorescent light (150 ft. candles).

Greenbouse Plants: Young tobacco plants were grown on sterilized soil in a well controlled greenhouse. They were harvested at a size comparable to that of the tissue culture plantlets.

Analytical Ultracentrifugation: Some 1 to $2 \mathrm{~g}$ of leaves from the above plant material were homogenized in 0.3 to $0.6 \mathrm{ml}$ of buffer containing $80 \mathrm{mM}$ Tris, $20 \mathrm{mM} \mathrm{MgCl}$ and $40 \mathrm{mM} \mathrm{KCl}$ ( $\mathrm{pH} \mathrm{8.5)}$. This was done with pestle and mortar at $4^{\circ} \mathrm{C}$. After centrifuging the slurry at 10,000 r.p.m. in a Sorvall for $10 \mathrm{~min}$, the supernatant was analyzed. The sedimentation pattern was obtained from the Beckman Model E analytical ultracentrifuge. Schlieren pictures were taken at 44,770 r.p.m., 10 to 20 min after attaining this speed. Sedimentation coefficients were calculated and corrected to water at $20^{\circ} \mathrm{C}$.

Determination of Protein and Cblorophyll Content: The protein content of the leaf homogenate obtained above was determined with the Model E analytical ultracentrifuge using known concentrations of RuBPCase as the standard. Photographs were taken 25 min after centrifugation at 44,770 r.p.m. and the area under each peak was measured. The protein in each sample was quantitated by comparison to areas on a standard concentration curve (9). Chlorophyll content was estimated in $80 \%$ acetone by the method of Arnon (10).

Analysis of Ribosomal RNA: Ribosomal ribonucleic acids (rRNAs), prepared by the method of Bourque et al. (11), were fractionated by polyacrylamide gel electrophoresis in $30 \mathrm{mM} \mathrm{NaH} \mathrm{PO}_{4}, 1 \mathrm{mM}$ EDTA, $36 \mathrm{mM}$ Tris$\mathrm{HCl}(\mathrm{pH}$ 7.2). Ratios were calculated from the area of each peak.

\section{RESULTS}

\section{The Content of Chloropbyll and Soluble Leaf Protein}

The morphological characteristics of the three genotypes of J.W.B. tobacco grown under greenhouse and tissue culture conditions have been described by Burk and Menser (5), Schmid (12) and Schaeffer and Menser (6). The wild type and yellow mutant seedlings and plantlets cultured on a modified Murashige-Skoog (MS) medium (8), lacking auxin and kinetin under low light conditions, exhibited less difference in total chlorophyll content than the greenhouse plants (Table 1). The addition of IAA, kinetin or a combination of the two to the seedlings or plantlets had little effect on their morphology with one exception. That is, when kinetin was added alone at $1 \mathrm{mg} / \mathrm{l}$ to the medium, the seedlings grew very slowly after germination. They developed small, thick, darkgreen cotyledons and leaves. Stems were thick as well and vigorous growth did not occur until some callus had formed at the base of the seedlings. Roots did not develop well in the presence of kinetin. No such effect was observed in the plantlets developed on MS medium containing equal amounts of kinetin and IAA. As seedlings grown in tissue culture, the wild type and yellow mutant plants could be distinguished only during the first two weeks after germination. However, the homozygous albino remained colorless. It contained only $6 \%$ of the chlorophyll when compared to the wild type plants under identical conditions (Table 1).

Table 1 shows that there is a $50 \%$ reduction in chlorophyll content from the wild type plantlets in vitro, whereas the yellow mutant plantlets contained essentially the same amount of this pigment under both in vitro and greenhouse conditions. In vitro the chlorophyll a/b ratio is considerably lower than observed in the greenhouse for both wild type and yellow mutant plants. However, the $\mathrm{a} / \mathrm{b}$ ratio of these two genotypes was close to the value determined for normal tobacco plants and consequently they could not be distinguished by their leaf color. The ratio for the albino plantlets is relatively high, which may indicate that their chloroplasts lack the light harvesting chlorophyll protein complex and the normal grana structure (13).

On a fresh weight basis, the wild type and yellow mutant seedlings or plantlets in vitro contained less $(20 \%)$ total soluble leaf protein than under greenhouse conditions (Table 1). In albino plants the amount of total soluble leaf protein and, in particular, the amount of the RuBPCase was greatly reduced.

Figure 1(A) represents a typical analytical ultracentrifuge Schlieren pattern of total soluble leaf proteins and free ribosomes extracted from wild type plants grown in the greenhouse. RuBPCase has a sedimentation coefficient of $18 \mathrm{~S}$ and is a chloroplast protein, whereas Fraction II (FII) protein has an S value of 4 to 6 and consists of soluble proteins derived from both the chloroplast and

Table 1. Content of chlorophyll and RuBPCase from different genotypes of John Williams Broadleaf tobacco under in vitro and greenhouse condlilons.

\begin{tabular}{|c|c|c|c|c|c|}
\hline \multirow{2}{*}{ Genotype } & \multirow{2}{*}{ Growth conditions } & \multirow{2}{*}{$\begin{array}{l}\text { Chlorophyll (mg) } \\
\text { per g fresh weight }\end{array}$} & \multirow{2}{*}{$\begin{array}{c}\text { Chlorophyll a / } \\
\text { chlorophyll b } \\
\text { ratio }\end{array}$} & \multicolumn{2}{|c|}{ RuBPCase (mg) per } \\
\hline & & & & mg chlorophyll & $g$ fresh weight \\
\hline su/su (wild type) & $\begin{array}{l}\text { greenhouse } \\
\text { plantlets }\end{array}$ & $\begin{array}{l}1.37 \\
0.65\end{array}$ & $\begin{array}{l}3.25 \\
1.91\end{array}$ & $\begin{array}{r}7.22 \\
12.46\end{array}$ & $\begin{array}{l}9.90 \\
8.10\end{array}$ \\
\hline Su/su (yellow mutant) & $\begin{array}{l}\text { greenhouse } \\
\text { plantlets }\end{array}$ & $\begin{array}{l}0.25 \\
0.25\end{array}$ & $\begin{array}{l}7.71 \\
2.57\end{array}$ & $\begin{array}{l}30.80 \\
26.80\end{array}$ & $\begin{array}{l}7.70 \\
6.90\end{array}$ \\
\hline Su/Su (albino) & plantlets & 0.037 & 7.84 & 41.08 & 1.52 \\
\hline
\end{tabular}


Figure 1. Analytical ultracentrifuge Schlieren patterns of soluble components extracted from tobacco leaves. A: from greenhouse plants of wild type (su/su) illustrating the proportion of $\mathrm{FI}$ protein (RuBPCase), Fll protein, $70 \mathrm{~S}$ and 80 S free ribosomes, B: from wild type (su/su) plantlets grown on Murashige-Skoog medium without indole-3-acetic acid and kinetin, and $\mathrm{C}$ : from albino (Su/Su) plantlets grown on Murashige-Skoog medium without indole-3-acetic acid and kinetin.

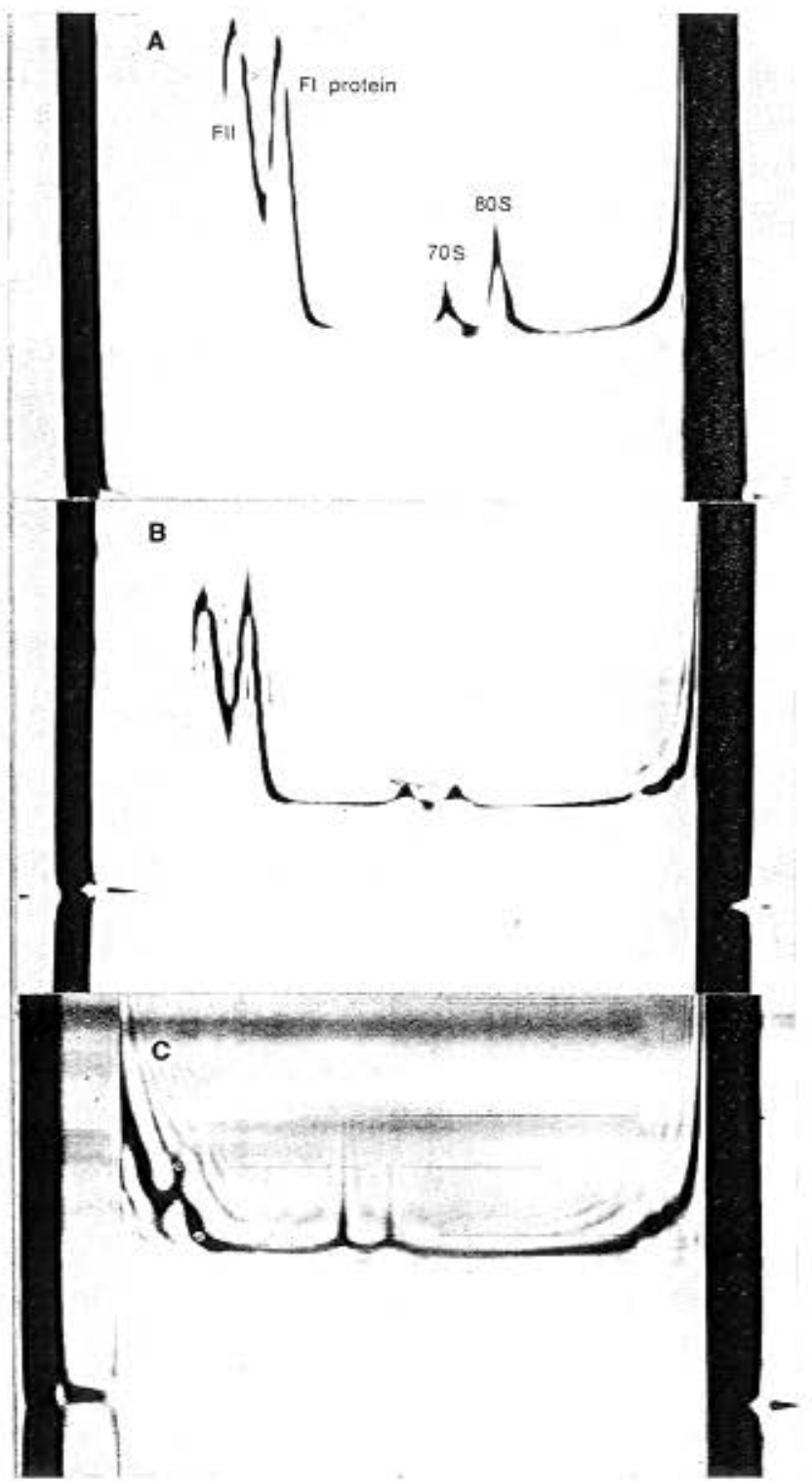

the cytoplasm. The three pictures in Figure 1 were taken at different bar angles and different times after reaching maximum speed in order to accentuate the differences among these tissues. Figures $1(A)$ and $1(B)$ are very similar, except that the plantlets cultured in vitro always have a lower level and different ratio of free $70 S$ and 80 S ribosomes. Albino plants (Figure 1(C)) have reduced levels of both RuBPCase and free ribosomes. These levels of RuBPCase and $70 S$ ribosomes, which are both of chloroplast origin, are great enough, however, to suggest that albino plantlets may contain many more chloroplasts than is apparent from the chlorophyll content.
Figure 3. The effect of indole-3-acetic acid or kinetin on the albino plantlets. A: control - no hormones were added to the medium, B: kinetin was added to the medium.

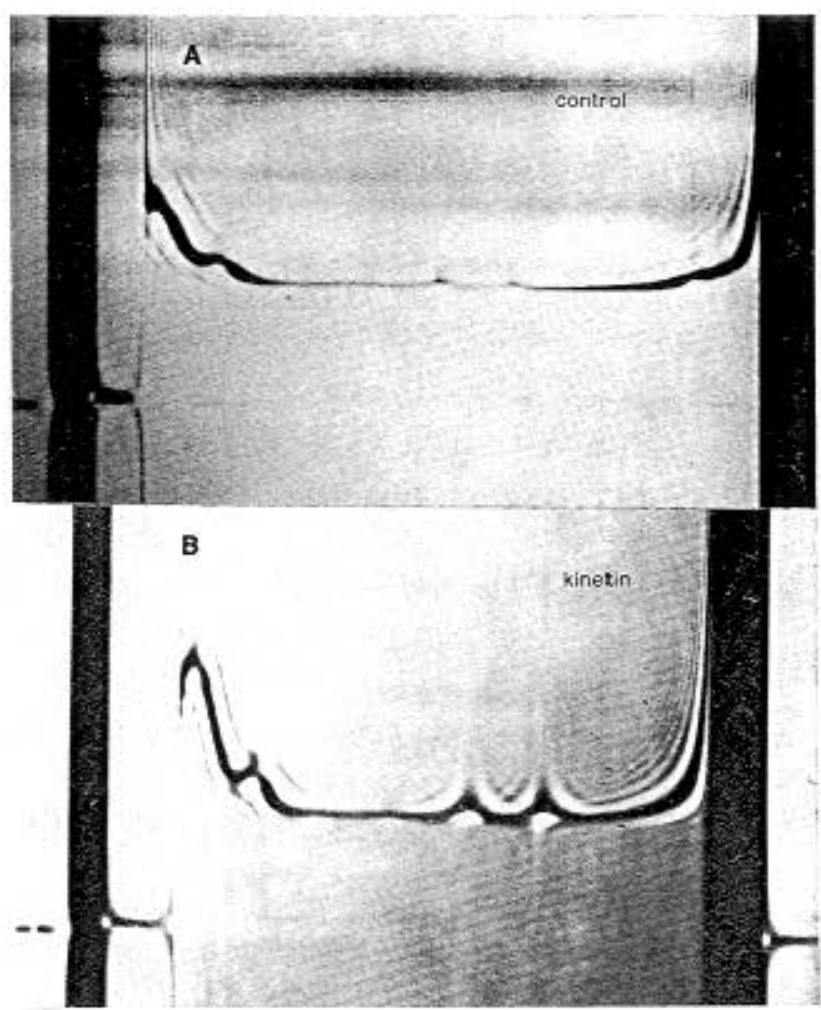

\section{Effect of $I A A$ and Kinetin on} RuBPCase and Free Ribosomes

Figure 2 illustrates the remarkable difference in the amount of RuBPCase from wild type plantlets grown on modified MS medium, with or without IAA and kinetin. The soluble leaf proteins and free ribosomes were extracted from an equal weight of fresh leaf tissue. The area under each peak is proportional to the concentration; therefore, these profiles can be directly compared. Without IAA and kinetin added to the medium (control), the wild type plantlets contained normal amounts of total soluble leaf proteins ( $16.2 \mathrm{mg} / \mathrm{g}$ fresh weight) divided equally between RuBPCase and FII proteins (Figure 2(A)). When IAA $(1 \mathrm{mg} / \mathrm{l})$ and kinetin (1 mg/l) were added to the medium, the amount of RuBPCase in the seedlings or plantlets was reduced to about 10 to $20 \%$ of the control with a slight decrease of the FII protein (Figure 2(B)). It should be noted that the free $70 \mathrm{~S}$ ribosomes disappeared when the plantlets were supplied with both hormones (Fig. 2(B) and Table 2). The remaining peak of the free $80 S$ ribosomes was also reduced. Since the ratio of $25 \mathrm{~S}+18 \mathrm{~S} / 23 \mathrm{~S}+16 \mathrm{~S}$ rRNA in all treatments (Table 2) remains relatively constant, there may be a shift from free to membrane-bound ribosomes in these hormone treated tissues. The combined effect of IAA and kinetin on the already suppressed levels of RuBPCase protein and free ribosomes in albino plantlets was insignificant when compared with that found in the other two genotypes (Table 2). 
Figure 2. The effect of hormonal treatment on the amount of RuBPCase and free ribosomes from plantlets. A: control - no hormones were added to the Murashige-Skoog medium, B: kinetin + auxin - equal amount of kinetin and indole-3-acetic acid (1 mg/l) was added to the Murashige-Skoog medium and leaves were harvested either from the seedlings or plantlets, C: kinetin - kinetin alone was added to the Murashige-Skoog medium and leaves were harvested from plantlets, and D: auxin - indole-3-acetic acid alone was added to the MurashigeSkoog medium and leaves were harvested from both seedlings and plantlets.

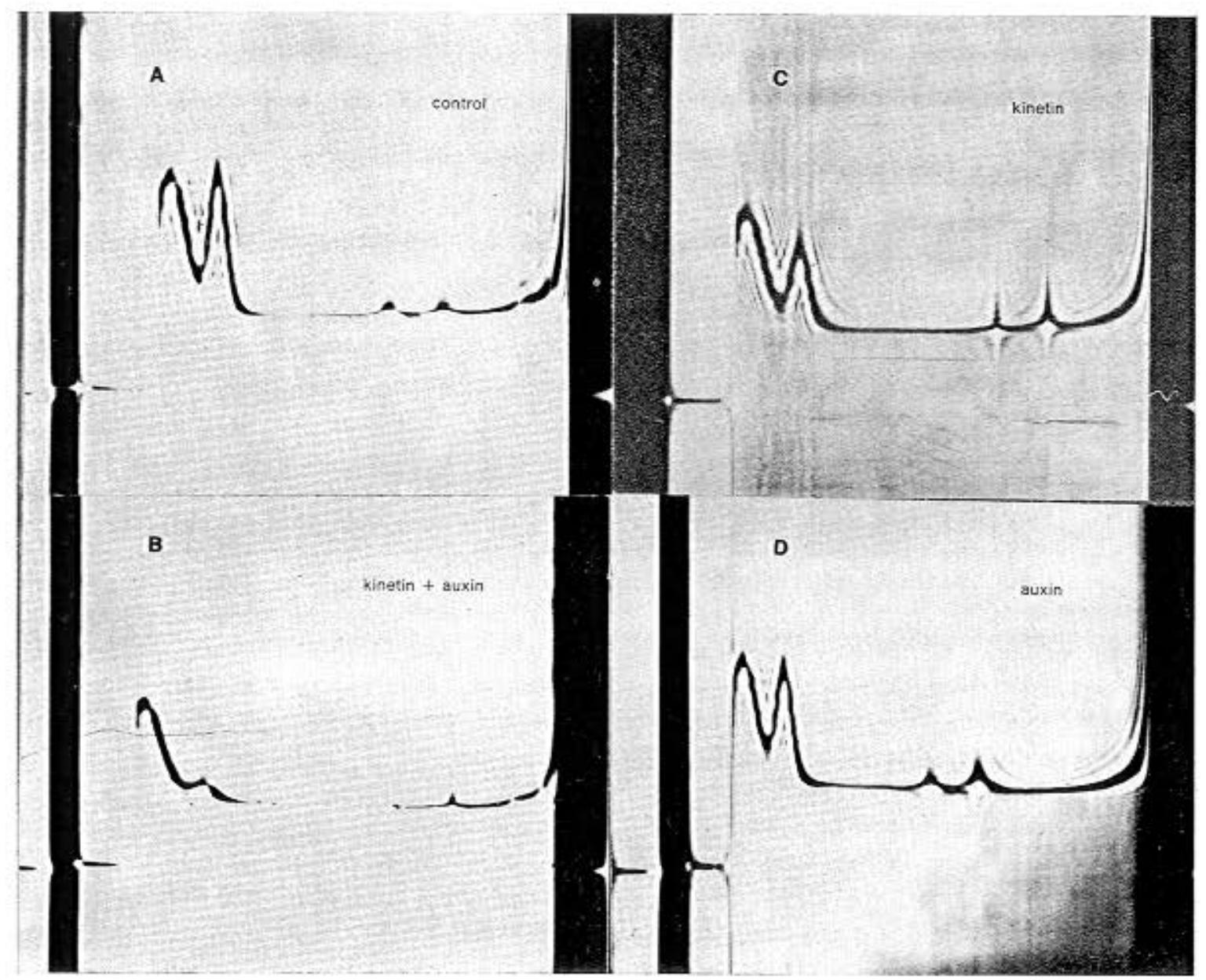

When IAA and kinetin were supplied individually to the plantlets, however, no reduction of RuBPCase or free ribosomes was observed (Figures 2(C) and 2(D)). When applied to seedlings, only the kinetin reduced the level of these soluble components. Without hormones, seedlings or plantlets usually had fewer free 705 and 805 ribosomes (with a 1:1 ratio) than did seedlings grown in the greenhouse, where the ratio of $70 \mathrm{~S}$ to $80 \mathrm{~S}$ ribosomes was $1: 3$ (Figs. 1(A) and 1(B), Table 2). When IAA or kinetin alone was applied to the plantlets, each caused an incremental increase of the free ribosomes to a level and ratio comparable to that in greenhouse grown plants (Figs. $2 \mathrm{C}$ and 2D). This stimulation was particularly evident in the case of albino plantlets (Fig. 3(B)), where a several-fold increase of soluble protein and free ribosomes was observed.

The presence or absence of sucrose in the medium had no apparent effect on the amount of total soluble protein. The hormones, when added to the medium individually or in combination, had no effect on the chlorophyll content of the seedlings or plantlets of either genotype.

\section{DISCUSSION}

This study was designed to investigate the role played by $I A A$ and kinetin in the regulation of RuBPCase synthesis. RuBPCase levels in tissues treated with or without hormones were compared by direct analysis of leaf extracts in the Model $\mathrm{E}$ analytical ultracentrifuge. This simple, rapid and reproducible procedure requires only a small quantity of leaf material ( $1 \mathrm{~g}$ fresh weight) and the results obtained were striking. When equal amounts of IAA and kinetin in MS medium were supplied to seedlings and plantlets, a drastic reduction in RuBPCase content was observed. Kinetin alone also suppressed RuBPCase levels when supplied to seedlings in the MS medium. In other instances, however, only plantlets treated with IAA or kinetin and added separately to the MS medium were stimulated to increase their RuBPCase and ribosome contents.

These hormone-induced alterations in the amount of RuBPCase were invariably accompanied by similar changes in the level of free ribosomes, particularly of 705 
Table 2. The effect of hormonal treatments on the raflo of soluble protein, free rlbosomes and rRNAs in vitro.

\begin{tabular}{|c|c|c|c|c|}
\hline Growth conditions & Genotype & $\begin{array}{l}\text { Soluble protein: } \\
\text { FII / RuBPCase }\end{array}$ & $\begin{array}{c}\text { Free ribosomes: } \\
80 S / 70 s \\
\end{array}$ & $\begin{array}{c}\text { Ribosomal RNA: } \\
25 S+18 S / 23 S+16 S\end{array}$ \\
\hline Greenhouse & $\begin{array}{l}\text { su/su (wild type) } \\
\text { Su/su (yellow mutant) }\end{array}$ & $\begin{array}{l}1 \\
1\end{array}$ & $\begin{array}{l}3 \\
3\end{array}$ & $\begin{array}{l}3-4 \\
3\end{array}$ \\
\hline $\begin{array}{l}\text { Tlasue Culture } \\
\text { Sucrose* }\end{array}$ & $\begin{array}{l}\text { su/su (wild type) } \\
\text { Su/su (yellow mutant) } \\
\text { Su/Su (albino) }\end{array}$ & $\begin{array}{l}1 \\
1 \\
3\end{array}$ & $\begin{array}{l}1 \\
1 \\
1\end{array}$ & $\begin{array}{l}3 \\
2-3\end{array}$ \\
\hline Sucrose plus IAA and kinetin* & $\begin{array}{l}\text { su/su (wild type) } \\
\text { Su/su (yellow mutant) } \\
\text { Su/Su (albino) }\end{array}$ & $\begin{array}{l}4 \\
4 \\
4\end{array}$ & $\begin{array}{l}\text { no detectable } 705 \\
\text { no detectable } 705 \\
\text { no detectable } 705\end{array}$ & $\begin{array}{l}3 \\
3 \\
2-5\end{array}$ \\
\hline IAA and kinetint & $\begin{array}{l}\text { su/su (wild type) } \\
\text { Su/su (yellow mutant) } \\
\text { Su/Su (albino) }\end{array}$ & $\begin{array}{l}4 \\
4 \\
4\end{array}$ & $\begin{array}{l}\text { no detectable } 705 \\
\text { no detectable } 705 \\
\text { no detectable } 705\end{array}$ & \\
\hline Sucrose plus IAA*\&+ & $\begin{array}{l}\text { su/su (wild type) } \\
\text { Su/su (yellow mutant) } \\
\text { Su/Su (albino) }\end{array}$ & $\begin{array}{l}1 \\
1 \\
2\end{array}$ & $\begin{array}{l}2 \\
2 \\
1\end{array}$ & \\
\hline Sucrose plus kinetint & $\begin{array}{l}\text { su/su (wild type) } \\
\text { Su/su (yellow mutant) } \\
\text { Su/Su (albino) }\end{array}$ & $\begin{array}{l}1 \\
1 \\
2\end{array}$ & $\begin{array}{l}2 \\
2 \\
1\end{array}$ & \\
\hline
\end{tabular}

* Leaves were harvested from seedlings.

+ Leaves were harvested from plantlets.

ribosomes. Such a strong correlation suggests that RuBPCase regulation may only reflect a more direct hormone-mediated effect on the protein synthesizing system. Reports of ribosome-associated cytokinin receptor proteins (14) and of stimulation of polyribosome formation by cytokinin (15) tend to support this view.

It is well known that kinetin and IAA can direct cells to divide and elongate and that differentiation is enhanced when the auxin/cytokinin ratio is low. It should be possible to investigate the relationship between RuBPCase levels and the differentiation process more closely with the goal of understanding how the level of this protein, which constitutes $50 \%$ of the total soluble leaf protein, may be manipulated. Recent studies have indicated that tobacco leaf proteins can serve as precursors of many undesirable smoke components which may be potential health hazards (16). Reduction or removal of soluble leaf proteins before the curing process may produce a safer smoking material. If extracted before the curing process, these proteins could serve as a food supplement (9). It is for these reasons that knowledge of the regulation of RuBPCase content could prove to be important in the production of safer smoking material, as well as a valuable protein source for-human consumption.

It should be of interest to mention that, unlike the diploid J.W.B. albino, albino plantlets of rice derived from anther cultures have been shown to be devoid of normal chloroplasts and to contain neither RuBPCase nor 705 ribosomes (18). It would be very revealing to examine this difference between the diploid and haploid albino plants.

\section{SUMMARY}

1. The three genotypes, $\mathrm{Su} / \mathrm{Su}, \mathrm{Su} / \mathrm{su}, \mathrm{su} / \mathrm{su}$, of John Williams Broadleaf tobacco (N. tabacum) grew equally well on Murashige-Skoog medium. On a fresh weight basis, the heterozygous ( $\mathrm{Su} / \mathrm{su}$ ) yellow mutant and the homozygous (su/su) wild type plants contain similar amounts of RuBPCase and Fraction II protein in roughly equal proportions, but with a somewhat reduced amount of 705 and $80 \mathrm{~S}$ free ribosomes. The homozygous albino ( $\mathrm{Su} / \mathrm{Su}$ ) plants contain appreciable amounts of RuBPCase and free $70 S$ ribosomes, although the chlorophyll levels are extremely low. In the case of the yellow and albino forms, there appears to be no correlation between RuBPCase and chlorophyll content.

2. When equal concentrations $(1 \mathrm{mg} / \mathrm{l})$ of kinetin and indole-3-acetic acid (IAA), or kinetin alone, were added to the medium, a drastic reduction of RuBPCase and disappearance of free $70 \mathrm{~S}$ ribosomes were observed in the yellow mutant and wild type plants, whereas the effect on the albino plants was not significant.

\section{ZUSAMMENFASSUNG}

1. Die drei Genotypen ( $\mathrm{Su} / \mathrm{Su}, \mathrm{Su} / \mathrm{su}, \mathrm{su} / \mathrm{su}$ ) von JohnWilliams-Broadleaf-Tabak (N. tabacum) wuchsen auf Murashige-Skoog-Medium gleich gut. Auf Frischgewichtsbasis war der Gehalt der heterozygoten gelben Mutante (Su/su) und des homozygoten Wildtyps (su/su) an RuBPCase und Fraktion-II-Protein bei etwa gleichem 
Mengenverhältnis, jedoch einer erwas verringerten Anzatll an freien 70S- und 80S-Ribosomen ungefähr gleich grols. Der homozygoto Albino (Su/Su) enchält erheblide Mengon an RuBPCase und freien 70S-Ribosomen, obwohl sein Chlorophyllobalt außerst niedrig ist. Boi der gelben Mutzate und beim Albino konnte keine Korrelation zwischen der RuBPCase und dem Chlorophyllgehalt beobacter werden.

2. Wenn detn Medium gleithe Mengen $(1 \mathrm{mg} / \mathrm{l})$ Kinetin und Indolyl-3-essigsäure (LAA) oder auch nur Kinetin zugesetzt wurden, waren bei der gelben Mutante und dem Wildryp ein starker Rüớgang des Gehaltes an RuBPCase und ein Verschwinden der freien 70S-Ribesomen zu beobachten, während sidh bei dem Albino keine signifikanten Auswirkungen zeigten.

\section{RESUME}

1. Les trois genocypes ( $\mathrm{Su} / \mathrm{Su}, \mathrm{Su} / \mathrm{su}, \mathrm{su} / \mathrm{su}$ ) de tabac John Williams Broadleaf ( $N$, tabacum) ont poussé de la méme façon sur le milieu Murashige-Skoog. Sur la base du poids fraiss le mutant jenne bétérozygote (Su/su) et le type sauyage homozygote (sw/su) contiennent des quantités semblables de RuBPCase et de protéines de la fraction II, en proportions a peu près tojales, mais arec une quantité légèrement rédujte de ribosomes libres 705 et 80S. Les plantes albinos homozygotes (Su/Su) contiennens des quantités considérables de RuBPCase et de ribosomes libres $70 S$ bien que les taux de dilorophylle soieat extremement bus. En ce qui conterne les formes jaunes et albinos, on $n^{\prime} a$ pas observé de corrélation entre Ia RuBPCase er le taux de chlorophylle.

2. Lorsque des quantités égales $(1 \mathrm{mg} / \mathrm{l})$ de cinétine et d'acide indol-3-acétique (IAA) on uniquement de la cinétine sont ajoutés au milieu, on observe une forte régression de la teneur en RuBPCise et la disparition des ribosomes $70 S$ libres dans le mutant jaune et la plante sauvage tandis que dans les plantes albinos cer effet n'est pas sigaificacif.

\section{REFERENCES}

1. Wildman, S. G., and J. Bonner: The proteins of green leaves; Arch Biochem. Bioptiys. 14 (1947) $381-413$.

2. Kung, S. D.: Tobacco Fraction I protein: a unigute genetic marker; Science 191 (1976) 429-434.

3. Feierabend, J., and J. de Boer: Comparatize amalysis of the action of cy tokinin and ligbt on the formation of RuBPCase and plastid biogenesis; Planta 142 (1978) 75-82.

4. Kung, S. D.: Expression of diloroplast genomes in ligher plants; Ann. Rev, Plant Physiol. 28 (1977) $401-437$.

5. Burk, L. G., and H. A. Menser, Jr, : A dominant Aurea mutation in tobacco; 'Tobacco Science 8 (1964) 101-104.

6. Stheffer, G. W., and H. A. Menser, Jr.: Tissue cultute of a tobaces albino mutant; Crop Setence 15 (1975) 728-730.
7. Sकaeffer, G. W.i Culture and morphogenetic response of a lethal, clorophyll-deficient mutant of tobaceo to bormones, amino acids and sucrose; It Vitro 13 (1977) 31-35.

8. Muraskige, T., and F. Skoog: A revised medium for rapid growth and bionssags with tobacco tissue cultures; Physiol. Plant 15 (1962) 473-479.

9. Kung, S. D., and T. C. Tso: 'Tobacco as a potential food source and smoke material; J. Food Sci. 43 (1978) 1844-1847.

10. Arnon, D. L.: Copper enzymes in isolated dloroplasts; Plant Physiol. 24 (1949) 1-23.

11. Bourque, D. P., A. Hagiladi and A. W. Naylor: A method for extracting intact dhloroplasts and cytoplasmic ribosomal RNA from leaves; Biochen. Biophys, Res, Conm, 51 (1973) \$93-999.

12. Schmid, G. H.: The influence of different light intensities on the growth of the tobacco Aurea mutant Su/su; Plant 77 (1967) 72-94.

13. Thornber, J, P.: Chlorophyll-proteins: light-barvesting and rexction center components of plants; Ant. Rer. Plant Physiol. 26 (1975) 127-15B.

14. Fox, J. E., and J. L. Erion: A cytokinin binding protein from bigher plant ribosomes; Biocten. Biophys. Res. Comm. 64 (1975) 694-700.

15. Fosket, D. E., M. J. Yoik and M. R. Goldsmith: Polyribosotnes formetion in relation to cytokinininduced cell division in suspension cultures of Glycine max (L.) Merr,; Plant Physiol. 60 (1977) 554-562.

16. Tso, T. C.: Progress in producing safer tobacco for less haroful cigarettes; World Smoking \& Health 5 (1980) $30-36$.

17. Kung, S. D., P. R, Rhodes, T. C. Tso and G. W. Schaeffer: The effects of nuclear tinutation on chloroplast development, I. Chloroplest DNA, proteins, ribosones, hormones in tissue cultures; Theoretical and Applied Genetics 1981, in press.

18. Sta, C. S., S. C. Wu, C. C. Wang and C. C. Chu: The deficiency of soluble proteins and plastid RNA in the albino pollen plantlets of rice; Theoretical and Applied Geretics 55 (1979) 193-197.

\section{Adenowledgements}

This study was supported by United States Department of Agricalture cooperative agreements 12-14-1001-967 and 12-14-1001-810 and National Science Foundation grant PCM-7812126 to S. D. Kung.

\section{Addresses of authors:}

S. D. Kkng,

Department of Biological Sciences, Unversity of Maryland Baltimore Connty, Catonsoille, Maryland, 21228, U.S.A.

G. W. Schaeffer,

Cell Culture and Nitrogen Fixation and Tobacco Laboratories, US. Department of Agriculture, Beltreille, Maryiand, 20705, U.S.A. 